第 17 回 日本臨床薬理学会 1996 年 11 月 $1 \sim 2$ 日 東京・京王プラザホテル

\title{
カキ肉エキスおよび高度不飽和脂肪酸含有油脂の アルコール代謝に及ぼす影響
}

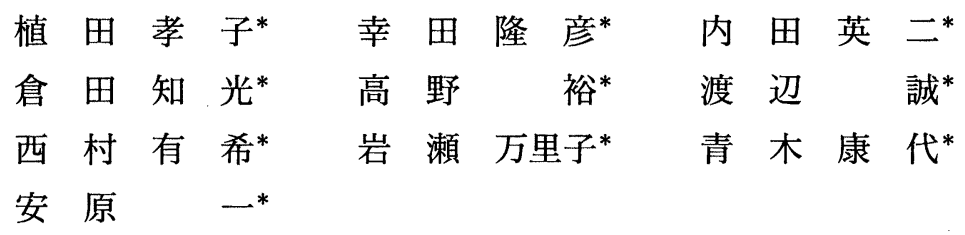

【緒言】今回試験に用いたカキ内エキスは天然の 牡期より醅素分解法により作成された市販のディ ノバランス（常盤薬品工業）である。また、高度 不飽和脂肪酸含有油脂(PUFA)はアラキドン酸を含 有する微生物抽出油(SUN-TGA25)、ドコサへキサエ ン酸を含有する魚油(DHA-30M)、エイコサペンタエ ン酸を含有する魚油(EPA-28g)およびシソ油を一定 の割合て配合した市販のサンバランス (パル薬品) である。これらの食品は動物实験並びにヒト試呀 において十分な安全性が確立されている。ラット にディバランスを投与するとエタノール及びア セトアルデヒドの血中浱度の上昇を㧕制すること か報告されており、PUFA併用によりさらに血中の エタノール、アセトアルデヒド浱度を低下させる ことが報告されている。これらの結果はカキ肉エ キスならびにPUFAがアルコール代謝に対しなんら かの影鳘を及ほすことを示唆している。

【目的】健常成人を対象に力キ肉エキスおよび高 度不飽和脂肪酸含有油脂のアルコール代謝に及ほ す影害について菜物動態学的パラメータを指醥と して梌討する。

【方法】女書にて同意を得た 8 名（年龄 $24.8 \pm$ 2.4藏、身長 $163 \pm 9.2 \mathrm{~cm}$ 、体重 $54.6 \pm 8.9 \mathrm{~kg}$ （mean \pm S. D. )を対象とし、プラセボを対照とした 2 群 2 期の二重盲検クロスオーパー法を用いた。 1 回目、試験参加者は試験食品（ディノバランス

\footnotetext{
$*$ 昭和大学医学部第二薬理学

于 142 東京都品川区旗の台 1-5-8
}

18 錠とサンバランス 6 カプセル) または外見が 同一なplaceboのどちらかを服用し、30分後に $0.3 \mathrm{~g} / \mathrm{kg}$ のアルコール（ウイスキー40-50ml）を服 用し、直後に水 $100 \mathrm{ml}$ を摄取した。血中エタノール 漫度、血中アセトアルデヒド浱度の測定を目的と して試唥食品摄取前、アルコール撕取 15、30、 $45,60,75,90,120,150,18$ 0 分の計 10 回静脈より $2 \mathrm{ml} /$ 回の採血を行った。 14 日間以上のrash out期間の後、1回目と同じ 手順で再度試験を行った。血中エタノール及びア セトアルデヒド浱度の測定はヘッドスペースガス クロマトグラフィー法で行った。検出限界はエ夕 ノール600 pg、アセトアルデヒド50 pgであった。 エタノールの薬物動態学的パラメーターは各個人 における血中浱度一時間曲線より、C $\max (\mu \mathrm{g} / \mathrm{m} \mathrm{l})$. $\operatorname{tmax}(\min ), \operatorname{AUC}(\mu \mathrm{g} / m \mathbf{m} \cdot \min ) . K_{0}:$ the rate of disappearance of ethanol $(\mu \mathrm{g} / \mathrm{ml})$. turnover rate $(\mathrm{mg} / \mathrm{kg} / \mathrm{h})$ ，見かけの分布容積 $\mathrm{V}(1 / \mathrm{kg})$ をそれ それ求めた。代謝物であるアセトアルデヒドに関 しては、Cmax (ng/ml), tmax (min), AUC (ng/ml • min)を求めた。薬物動態学的パラメータの算出に はSiphar V.4.0を用いた。食品投与群とplacebo群 で算出した薬物動態学的パラメータの群間比較に 関してはpaired t-testを用いた。血中のエタノー ルおよびアセトアルデヒド涱度一時間曲線に関し てはrepeated measures ANOVA(RMANOVA)を用い、 treatment effectあるいはtreatment time effec tに有意差が認められた場合には、paired t-test による検定を各時点で行った。統計解析にはSPSS R6.0を使用した。 


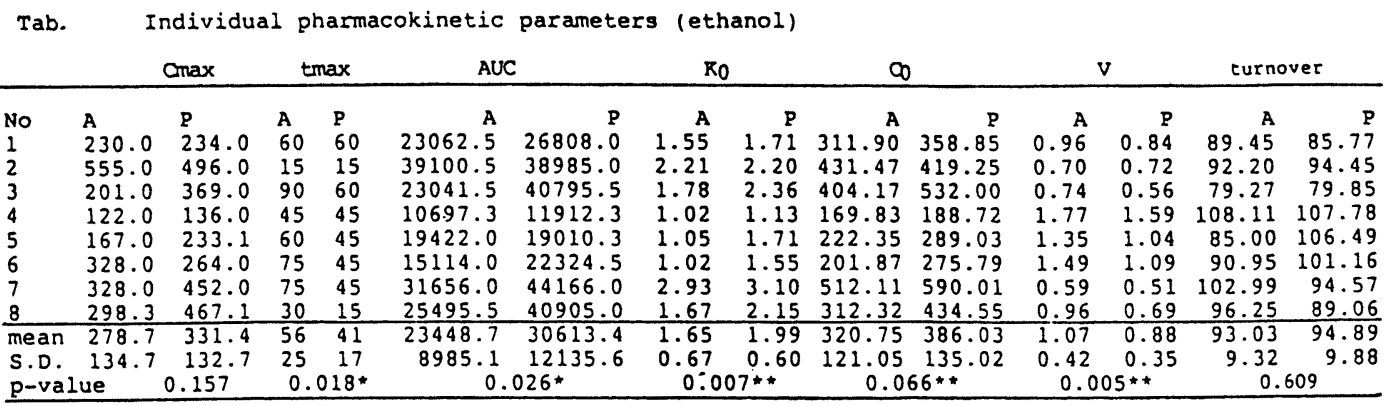

A; active treatment, P;placebo treatment

$* 0<0.05 * 0<0.01$, performed by paired $t$-test

Cmax $(\mu \mathrm{g} / \mathrm{ml})$; maximum blood ethanol concentration

$t \max (\min )$; time to reach to Cmax

AUC $(\mu \mathrm{g} / \mathrm{ml} \mathrm{min})$; area under the ethanol concentration-time curve

$\mathrm{K}_{0}(\mu \mathrm{g} / \mathrm{ml} / \mathrm{min})$; slope of the regression line in the elimination phase

$\mathrm{C}_{0}(\mu \mathrm{g} / \mathrm{ml})$; the $\mathrm{Y}$-intercept of the regression line

$\mathrm{v}(1 / \mathrm{kg})$; apparent volume of distribution

turnover $(\mathrm{mg} / \mathrm{kg} / \mathrm{h})$; the rate of removal of ethanol from the body

なお、本試験のプロトコールは昭和大学医学部臨 床試験審査委員会で承認を受けた。

【結果】Placebo群と食品服用群のエタノール平均 血中濃度一時間曲線の間にはRepeated Measures ANOVA (RMANOVA)にて"treatment ef fect"および "treatment by time effect"の両方で $p=0.022$ と有 意差を認め、30 分 $(p=0.015)$ 及び 60 分 $(p=0.03$ 0)においては食品服用群において有意な低下を認 めた。エタノールの薬物動態学的パラメータを比 較すると、食品投与群ではplacebo群よりもtmaxは 有意に遅延し、AUCの有意な減少、Koの有意な低下、 C。の有意な低下、Vの有意な增加が認められた（ $p<$ 0.05)。Cmax及びturnover rateには有意差を認め なかった(Tab.)。アセトアルデヒドの平均血中浱 度一時間曲線の間には有意差は認められなかった が、採血を行った全てにおいて平均血中アセトア ルデヒド浱度は食品服用群においてplacebo群に比 ベ低値を認めた。アセトアルデヒドの薬物動態学 的パラメータ (Cmax, tmax, AUC) は個々のばらつき が大きく、両群間で有意差を認めなかった。AUCは 試験食品により著明に減少した者が 4 例、少し減 少した者が 1 例、ほとんど変化がなかった者が2 例、著明に増加した者が 1 例であった。著明にAU Cが低下した 4 例のエタノールの血中浱度一時間曲 線との関連を検討すると、食品投与により明らか にエタノールの吸収が達延した型とエタノールの AUCがほとんど不変である型が認められた。

【考察】エタノールの血中濐度一時間曲線より考 察すると、平均血中浱度に対して食品服用群の
平均血中浱度が有意に低下している時間は 30 分 と60 分のみであるが、30分から120分にか けて血中濐度は低下する傾向にあり、150 分、 180 分では両曲線の差が減少する傾向にあるこ とがわかる。つまり、食品服用群では吸収総量が 減少し、tmax前後の血中濃度は低下するものの、 血中からのエタノール消失速度が低下するため、 placebo群との差が小さくなったものと考えられる。 しかし、吸収が著明に遅延し、長時間に渡り徐々 に血中にエタノールが吸収されるため、見かけ上 の血中エタノール消失速度が低下している可能性 も考えられる。エタノール代謝を正確に判定する ためには、吸収相の消失相に与える影響を排除す る必要がある。今回のデータを詳細に検討するに は、エタノールを静脈内投与し、同様のデザイン にて薬物動態を比較検討する必要があるものと考 えられる。アセトアルデヒドの薬物動態学的検討 では、食品撕取により明らかにエタノールの吸収 が遅延した型においてはエタノールの吸収と代謝 速度により理解することができる。が、エタノー ルのAUCがほとんど不変である型の場合、アセトア ルデヒド代謝系への影響も考えられる。しかしデ 一タのばらつきの大きさもあり、これらの結果の みで結論することはむずかしいと思われる。比較 的酒に弱いタイプ（6例）において多少なりとも アセトアルデヒドのAUCが減少している者が5例、 強いタイプ（2 例）では変化を認めなかったこと より食品によるアルコール代謝への影響は弱い夕 イプにおいてより鋭敏に認められる傾向が示唆さ れた。 